Article

\title{
Crossing the Line between News and the Business of News: Exploring Journalists' Use of Twitter
}

\author{
Stephen Jukes \\ Faculty of Media and Communication, Bournemouth University, Poole, BH12 5BB, UK; E-Mail: sjukes@bournemouth.ac.uk
}

Submitted: 7 September 2018 | Accepted: 4 January 2018 | Published: 21 March 2019

\begin{abstract}
Anglo-American journalism has typically drawn a firm dividing line between those who report the news and those who run the business of news. This boundary, often referred to in the West as a 'Chinese Wall', is designed to uphold the independence of journalists from commercial interests or the whims of news proprietors. But does this separation still exist in today's age of social media and at a time when news revenues are under unprecedented pressure? This article focuses on Twitter, now a widely used tool in the newsroom, analysing the Twitter output of 10 UK political correspondents during the busy party conference season. It examines how they promote their own stories or 'personal brand' and whether they are stepping over a once forbidden line, blurring the boundary between news and the business. The research is complemented by interviews with political correspondents and analysis of editorial codes of practice on the use of social media. It draws on a conceptual framework of boundary work (Carlson \& Lewis, 2015) to pose the question whether such practice has now become accepted and normalised. The findings suggest that the 10 political correspondents are highly individualistic in their use of Twitter but all have embraced its use to promote their own work plus that of colleagues both inside their own organisation and those working for rival news outlets. Their acceptance of Twitter as a tool for self-promotion and branding suggests that in this area of reporting the practice has become normalised and the wall has been breached.
\end{abstract}

\section{Keywords}

boundary work; business; journalism; social media; Twitter

\section{Issue}

This article is part of the issue "Journalism and Social Media: Redistribution of Power?", edited by Marcel Broersma and Scott Eldridge II (University of Groningen, The Netherlands).

(C) 2019 by the author; licensee Cogitatio (Lisbon, Portugal). This article is licensed under a Creative Commons Attribution 4.0 International License (CC BY).

\section{Introduction}

Back in the old days of journalism, in the era before social media when newspapers enjoyed rich earnings, few reporters would spend time thinking about profitability or their employer's business. As Alan Rusbridger, the former editor of The Guardian, remarked in his autobiography (2018), there was simply no need to talk about business models when he started out in the mid-1970s. The Anglo-American norms of journalism that evolved on both sides of the Atlantic in the late 19th century were still intact and prescribed a strict separation between news and the business of news. The goal was very simple: to uphold the editorial integrity of independent journalism, untarnished by considerations of advertising rev- enues, the bottom line or the personal whims of news proprietors. In the jargon of the newsroom, this boundary was called a 'Chinese Wall.'

Throughout North America, Europe and many other parts of the world, that separation held good for more than a century as a fundamental norm of journalism (Cornia, Sehl, \& Nielsen, 2018, p. 20). But does it still exist today when many news organisations are struggling to survive and adapt to the sweeping changes wrought by social media? This article explores one specific part of the equation, namely the use of Twitter which has rapidly become a ubiquitous tool in the newsroom. It examines the Twitter output of 10 seasoned UK political correspondents during the annual party conference season in September 2018, a time of frantic political ac- 
tivity and infighting as Britain entered the final stages of negotiations to exit the European Union, commonly known as 'Brexit'. The analysis is complemented by interviews with political journalists and an examination of their news organisations' codes of practice on the use of social media. Previous research has focused on the way journalistic norms are evolving in this period of disruption when pressures of the market become stronger (Hanusch \& Tandoc, 2017, p. 4). Several studies have explored journalists' use of social media to brand themselves and their organisations (Barthel, Moon, \& Mari, 2015; Brems, Temmerman, Graham, \& Broersma, 2017; Lough, Molyneux, \& Holton, 2017; Molyneux, 2015; Molyneux \& Holton, 2015; Molyneux, Holton, \& Lewis, 2018) while others have focused on the ways journalists present their personal and professional identities online (Bossio \& Sacco, 2017; Olausson, 2017). But few have directly addressed the issue of the Chinese Wall, journalists' perceptions of whether this norm is under attack and what they feel about it today. How do the political journalists, working in the 'lobby' system of parliament at Westminster, promote their own stories or those of their respective news organisations at a time when audience engagement is increasingly important? Do they feel that they are stepping over a forbidden line and blurring the boundary between news and the business? Or is it now viewed as an acceptable practice? The article draws on a conceptual framework of boundary work (Carlson \& Lewis, 2015) and seeks to contribute to the debate about how what it means to be a journalist is being redefined. The results of the research suggest that the 10 political correspondents, although all covering the same story, are highly individualistic in their use of Twitter as a branding tool. All have embraced its use to promote their own work plus that of colleagues and those working for rival news outlets. The acceptance of Twitter as a tool for self-promotion and branding by senior journalists who are by no means 'digital natives' suggests that in this narrow field of British reporting the practice has become normalised and the wall has been quietly breached.

\section{How Separation Became the Norm}

Many professions erect boundaries around their activity to protect themselves from intruders and journalism is no exception. But unlike, for example, Law or Medicine, Journalism does not require exams or membership of an industry association. Instead, the boundaries are defined through practice, discourse and values, with journalists engaging in 'boundary work' to cultivate a distinct logic that sets them apart from other fields (Waisbord, 2013 , p. 10). The concept stems from the U.S. sociologist Thomas Gieryn (1983) and has recently gained a foothold in Journalism Studies in the light of the decline of legacy media outlets and the rise of social media (Carlson \& Lewis, 2015). The emergence and growth of new media forms throughout the 20th century repeatedly generated defensive responses, couched in normative terms loosely grouped under the term 'objectivity', from many of the established practitioners of the day (Singer, 2015, p. 23).

One of the key tenets of that consensual occupational ideology is journalistic independence or autonomy. For Coddington, the separation of the business of news from news itself is so fundamental that it is simply known as 'the wall' (2015, p. 67). And as long as newspapers prospered, journalists were able to believe that they had succeeded in building a wall between 'church and state' $(2015$, p. 70$)$. This often manifested itself through physical separation: the newsroom and business sides of a newspaper were on separate floors. But today, 'native advertising' has become a regular feature of the media landscape. Critics call such content advertising wearing the uniform of journalism (Coddington, 2015, p. 76). But as Richards observes, while the journalist may be the essential unit of ethical agency, he or she does not operate in a vacuum - many are employees of large corporations, the primary aim of which is to maximise the return to shareholders (2004, p. 119). In other words, journalists are now feeling the pressure of participating in the market for audience clicks and adopting the role of marketer (Tandoc \& Vos, 2016, p. 960). This poses the question whether the 'wall' is ripe for renegotiation (Artemas, Vos, \& Duffy, 2018, p. 1004). As more and more journalists set out on their own, or work for start-ups, they might wear multiple hats, producing content but also being a marketer, advertising executive and business manager (Singer, 2015, p. 30). Cornia et al. argue that both editors and managers are working to foster a cultural change to ensure commercial sustainability $(2018$, p. 2).

\section{Twitter-Not Just a News Gathering Tool}

One of the catalysts for the challenging of boundaries has been Twitter. It now has 335 million active users worldwide; within the UK, there are 13 million users while some 500 million tweets are sent each day worldwide. Since its launch in 2006, Twitter has become the most widely used social media tool by journalists (Parmelee, 2013), developing into an essential mechanism for the distribution of breaking news and as a tool to solicit story ideas, sources and facts (Hermida, 2010, p. 299). In fact, it has taken on the character of a convenient, cheap and effective 'beat' for journalists, offering a large range of sources who would otherwise be hard to approach (Broersma \& Graham, 2013, p. 447). This is essential in an environment in which newsgathering resources have often been cut and in which reporters are expected to write more stories (Broersma \& Graham, 2013). Hermida calls Twitter an 'awareness system' that can alert journalists to breaking news and trends (2010, p. 304). At the same time, news organisations have adopted Twitter as a means of distributing short, rapid updates on news they are producing and, sometimes, on that from third parties. This has led to fears that tweets are being indiscriminately incorporated into stories without fact check- 
ing. Failure to contact the person tweeting erodes journalism as a practice of verification (Broersma \& Graham, 2013, p. 461).

It is also now common for journalists to leverage such tools to show a human face to their audience or readers, especially in the online environment (Barnard, 2016, p. 198). As a result, research has focused on how roles, values and norms are evolving (Bossio \& Sacco, 2017). A consistent theme is the incorporation of journalists' own opinion in tweets, at odds with the classic definition of objectivity. In her study of two London-based journalists using Twitter to disseminate breaking news on innercity rioting in 2011, Vis concluded that more than one fifth of the tweets sent by a New York Times journalist contained his own opinion (2013, p. 42). Equally, Brems et al. found that a sample of Dutch and Flemish journalists were quite willing to voice their own opinion on Twitter (2017, p. 452). The use of retweets additionally provides an opportunity for journalists to pass on opinions without the threat to their objectivity if they stated the same words themselves (Molyneux, 2015, p. 928). Twitter also sits uneasily with another norm, the traditional detachment from journalists' sources and the audience (Molyneux, 2015, p. 922). But all this comes at a time when newsrooms are recognising an increasing need to engage with their audiences and be responsive to communities (Mayer, 2011). This, Mayer adds, means journalists have to build connections and personalise their brand.

In the light of such overt challenges established news organisations have updated internal editorial guidelines to incorporate social media. Duffy and Knight analysed codes at 17 news organisations and found the use of social media was generally embraced but with the cautionary message that it was also risky $(2018$, p. 8). Codes differed in the crucial area of the journalist's identity. The majority, 11 out of 17, made it clear the news organisation expected the professional identity to take precedence over, even subsume, any personal identity. Others required journalists to keep these personae separate and avoid any blurring of lines. Such codes of conduct have not always found favour among journalists. A study of Flemish journalists showed that some considered codes a curtailment of individual freedom and resisted a requirement to use only one Twitter account (Opgenhaffen \& Scheerlinck, 2014, p. 726). Some guidelines tended to treat Twitter as a branding and promotional opportunity (Bloom, Cleary, \& North, 2016, p. 352); a study of news managers at U.S. network affiliate television stations found they also viewed Twitter as a valuable promotional tool (Lysak, Cremedas, \& Wolf, 2012, p. 203).

It is widely recognised that social media allow individuals to construct and re-imagine the self (Siapera, 2018), a concept that has been called 'presencing' or 'sustaining a public presence' (Couldry, 2012). When it comes to journalists, Barthel et al. argue that Twitter provides an ideal platform to gain visibility, credibility and prestige $(2015$, p. 2). This enables them to increase their market value or, in the case of freelancers, advertise their skills (Brems et al., 2017, p. 445). Some specialised groups of journalists such as health reporters have been particularly active in developing a digital identity as 'early adopters' (Molyneux \& Holton, 2015, p. 226). Molyneux et al. argue that journalists engage in three levels of 'branding' ${ }^{1}$ through their use of Twitter: promoting the self, their employer's news organisation and the institution of journalism at large (2018, p. 1386). As a result, journalistic branding is a product of several pressures that journalists, their organisation and their occupation are facing (Molyneux et. al, 2018, p. 1391). Their study of U.S. journalists found that $58 \%$ of their tweets included elements of branding. Some studies based on interviews with journalists have also highlighted journalists' concerns about a growing emphasis by employers on personal branding (Chadha \& Wells, 2016, p. 1028). While they recognised the value in raising their profile and status in a newsroom, they expressed reservations that a personal brand could outstrip that of the news organisation, running counter to the normative ideology discouraging the development of a journalist's individual public persona (Chadha \& Wells, 2016, p. 1029). Similarly, Sacco and Bossio identified in their study of Australian newsrooms a culture clash between traditional journalistic values and management attempts to integrate social media (2017, p. 187).

Political journalists enjoy a unique position as a mediator of power in the relationship between politicians and the public and depend on trust and credibility (Ottovordemgentschenfelde, 2017, p. 68). They often work on a narrowly focused beat and in a bounded space outside the main newsroom, for example in the House of Commons 'lobby'. Such environments are known for their intense, close-knit journalistic communities with the ability to engage in off-the-record conversations with politicians. A study of reporters working in the State Capitol Building in Albany, New York, found the use of Twitter generated intense news-breaking pressure (Revers, 2015, p. 8). One reporter called it a "huge classroom" where everyone was able to monitor everyone else (Revers, 2015). An analysis of tweets during the 2016 U.S. election by political correspondents found they tended to interact mostly with each other, banding together as a community to shore up a profession they see as under threat (Molyneux \& Mourão, 2017, p. 15). The close-knit nature of political reporting suggests that such reporters tend to retweet others who are working in the same arena. Barthel et al. found that 'traditional' journalists overwhelmingly retweeted those from other traditional news organisations and rarely ones working in the digital-only sector (2015, p. 13).

\section{Research Questions and Methodology}

This study seeks to make a contribution to the understanding of how one group of political journalists in the

\footnotetext{
${ }^{1}$ Branding is understood as the action of differentiating an individual, entity or product from others (Murphy, 1987).
} 
UK uses Twitter as a means of branding and whether they feel there are tensions with the norm of separation between their news reporting and the business of news. In such a context, it is important to explore how journalists are changing practice alongside how they conceive their role (Tandoc \& Vos, 2016, p. 954). The study thus seeks to construct a holistic picture of their branding activity and addresses three interlinked research questions:

RQ1: How do UK political correspondents brand themselves, their news organisation or the profession of journalism through their use of Twitter?

RQ2: What guidelines are political correspondents subject to from their employers when they use social media tools such as Twitter?

RQ3: Do UK political correspondents feel their activity is consistent with the traditional norm of separation between news and the business of news?

The study is based on a quantitative and qualitative analysis of the Twitter activity of 10 top UK political correspondents in September 2018 and the first days of October. This is supplemented by an analysis of their Twitter profiles, codes of practice and semi-structured interviews. This was a time of turmoil in British politics, with Brexit negotiations at a critical stage. September is also the conference season when the main parties gather to debate their policy agendas. The period of 33 days covers the time from the end of the summer break until the final day of the Conservative Party conference on October 3.

These correspondents are part of what in the UK is known as the lobby system. Their accreditation gives them special access to daily briefings by the government's spokesman and to the Houses of Parliament, a system in place since the 1870 s. Today, it is still a closed environment in which reporters work closely alongside each other and politicians. Twitter is deeply embedded in that culture and has been attacked by Guardian journalist Rafael Behr for distorting and corrupting the political process (2018). Behr considers Twitter to be ideally suited to the political hothouse of Westminster and while individual journalists are looking for their own scoop, there are times when they operate as a 'pack' (2018, p. 22): "Journalists and commentators 'follow' each other, gathering at the virtual water cooler. This exacerbates the tendency to form cartels of information."

The 10 journalists were selected in order to obtain a cross section of lobby reporting from broadcasters and print media. Each had an active Twitter feed and was covering the main political and Brexit story dominating British headlines. Most of those chosen were the news organisation's senior political reporter, some of them household names on evening television news bulletins. Three were chosen from the BBC given the organisation's blanket coverage of Westminster, plus the chief politi- cal correspondent of each of the other three main news broadcasters-ITV, Sky and Channel 4. In addition, the lead political correspondents from four daily newspapers were chosen, ensuring a broad spectrum in terms of political outlook and editorial stance on Brexit. The broadcasters were Laura Kuenssberg, John Pienaar and Chris Mason of the BBC, Robert Peston, ITV, Faisal Islam, Sky, and Gary Gibbon, Channel 4. The newspaper journalists were: Heather Stewart of The Guardian, Francis Elliott, The Times, Gordon Rayner, The Telegraph, and Jason Groves, The Daily Mail.

All their tweets from September 1 to October 3 were captured to conduct the content analysis which included a quantitative assessment of their output and a qualitative analysis of their actual tweets and retweets. A codebook was created which drew on the categorisation used by Molyneux et al. (2018). It collated the total number of tweets and retweets during the period for each journalist and two sets of data. The first focused on the nature of the tweet or retweet-whether the subject matter was political or events outside Westminster, e.g. references to sport, humour, entertainment, etc. The second categorised tweets and retweets for brandingelements of individual branding (referring to or promoting the journalist's own work), elements of organisational branding (referring to or promoting the work of a colleague), and institutional branding (referring to or promoting the work of journalists at another news outlet or an issue about journalism). The first category did not include tweets where correspondents were reporting breaking news in snippets, often the case during conference speeches.

This breakdown was supplemented by an analysis of the correspondent's Twitter profile and their organisation's code on the use of social media. The analysis of the Twitter profile focused on whether the journalist stated his or her affiliation, the actual Twitter 'handle' (whether it contained the news organisation or not), whether there was any form of disclaimer about personal opinion offered and whether additional personal information was given beyond the reporter's 'beat'. The disclaimer is particularly relevant in connection with retweets and any public perception that retweeting information implies endorsement of that person's views, or, in the case of politicians, their party's views. Editorial guidelines for six of the eight news organisations were publicly available through their websites ${ }^{2}$.

Semi-structured interviews were conducted during the same time period with seven broadcast and newspaper journalists about their Twitter activity and their views on editorial policy. These were conducted in person or over the phone and for pragmatic reasons of availability included some journalists outside the group of 10 whose Tweets were analysed. All the journalists were, however, closely involved in covering the Westminster story. Critically, all were senior and had been working as journal-

\footnotetext{
2 These were: the BBC, ITV, Channel 4, Sky, The Guardian and The Telegraph. The Times refers to the Editors' Code of Practice as drawn up by the Independent Press Standards Organisation (IPSO).
} 
ists well before the introduction of Twitter in 2006 or other social media tools. The discussion of findings uses the names of the 10 correspondents whose tweets were tracked but the data and quotes from those interviewed were anonymised.

\section{Findings and Discussion}

\subsection{Lobby Correspondent Profiles}

The starting point for how the lobby correspondents brand themselves is their profile on Twitter. It is, by definition, a form of branding (Molyneux et al., 2018, p. 1395).

All 10 begin their profile with a designation of their role and news affiliation (see Table 1 ). Two of the BBC journalists, Laura Kuenssberg and Chris Mason, use the BBC handle (e.g., @bbclaurak) in line with the organisation's guidelines, thus making it clear that tweets are part of their work for the BBC and not a personal account. John Pienaar, the deputy political editor of BBC News, uses @JPonpolitics, a handle that promotes his weekly political podcast Pienaar's Politics. Two of the newspaper correspondents also use a formulation to highlight their affiliation, The Guardian and The Times (@GuardianHeather and @ElliottTimes). All three BBC correspondents highlight their beat by featuring a picture of the Houses of Parliament or Big Ben in their profile as does Channel 4's Gary Gibbon and the Telegraph's Gordon Rayner. The banner picture on Kuenssberg's profile features a scrum of photographers with her standing out in blue against the predominantly grey sea of the others. ITV's political editor uses a picture of his recently published book on the current political climate, together with a banner promoting it featuring a positive review in the Financial Times "Richly argued and brilliantly written." With the exception of the BBC correspondents and Channel 4's Gary Gibbon, the others are casually dressed, projecting an informal identity. By way of comparison, Lough et al. analysed the Twitter profiles of 384 journalists in the United States and found that $67 \%$ were in professional attire (2017 p. 1284).

Table 1. Twitter profiles.

\begin{tabular}{lc}
\hline Element in profile & No/10 \\
\hline Name of employer and role & 10 \\
Employer name in Twitter handle & 6 \\
Picture of parliament & 5 \\
Professional attire & 4 \\
Disclaimer on views & 2 \\
Personal interests outside beat mentioned & 5 \\
\hline
\end{tabular}

Only two of the 10 use a disclaimer. Jason Groves of The Daily Mail writes: "Views my own, I am afraid," typical of the self-deprecating humour often found in the group's tweets. Kuenssberg states: "Retweets not my own or BBC's view." This clearly reflects an awareness of the inherent danger in retweeting in the political arena and the BBC's Editorial Guidelines (2018) on micro-blogging which, in reference to Twitter, state: "When forwarding or 'retweeting' messages, care should be taken that it does not appear that the BBC is endorsing a particular opinion."

When it comes to personal interests, the BBC's Chris Mason mentions that he is a "Yorkshire Dalesman" (several personal tweets revolve around Yorkshire) while Robert Peston cites his support for the Arsenal football team. In a similar vein, Gordon Rayner laments the poor performance of the team he supports, calling himself a "long-suffering" Newcastle United fan. In this way, these journalists were blurring the line between their personal and professional identity.

\subsection{Editorial Guidelines}

The editorial guidelines issued by the lobby correspondents' news organisations strike a consistent tone, treading a fine line between embracing the benefits of social media and warning of potential pitfalls. Typical of this is the BBC (2015):

Social media is now critical to our work, allowing us to more easily connect with people.....But social media easily blurs the line between the personal and professional, and the simplest misstep could lead you to undermine the credibility of yourself, your colleagues, and BBC News as a whole.

The BBC makes it clear that the social media activity of its editors, presenters and correspondents should be viewed as 'official,' with the same status as their mainstream TV, radio or digital output. At the same time, the guidelines attempt to give correspondents scope to express themselves outside their 'beat', saying such discussion is actually encouraged (giving free rein to Chris Mason to sing the praises of his native Yorkshire). "Social media," the BBC guidelines say, "is all about personality and being human" (2015).

While these guidelines tread a narrow line, they bring social media tools like Twitter within the normative framework of their editorial codes. This theme necessarily runs through guidelines drawn up by all the news broadcasters which are overseen by the regulator Ofcom. Channel 4 News states that when a journalist is using Twitter with a designated account, postings are subject to Channel 4's normal controls, such as standards of due impartiality, editorial independence and accuracy (2018). ITV guidelines specifically reference Ofcom; Sky's guidelines make clear that nothing should be tweeted or retweeted that the broadcaster would not be prepared to put on any of its platforms (2017). The lobby correspondents' respective newspapers show very little difference in attitude in this respect. The Telegraph states that editorial independence must be maintained and must not be influenced by commercial staff or the interests of advertisers. But it also suggests a subtle shift, saying 
(2018): "It is entirely appropriate, and indeed essential, that editorial staff understand and contribute to the commercial success of the Telegraph."

\subsection{Twitter Activity}

The level of the lobby correspondents' Twitter activity varied widely but generally peaked as the Labour and Conservative parties held their conferences. Many of the correspondents were reporting-and tweetinglive from the conferences in the cities of Brighton, Liverpool and Birmingham, often uploading pictures of the proceedings.

The raw data (see Table 2) show that the most prolific 'tweeters' were in equal measure the BBC's Laura Kuenssberg and Chris Mason, both with around 440 tweets and retweets during the September 1-October 3 period, followed by The Guardian's Heather Stewart with a total 392. Almost all used Twitter as a means of personal branding, often promoting their own stories, television shows or podcasts. In addition, they frequently referred to work by their colleagues covering the same field of Westminster politics, sometimes praising their stories and sometimes promoting their news organisation directly. Occasionally, they would act in concert and retweet and credit a scoop by one of their rivals in the lobby. When Francis Elliott of The Times broke an exclusive Brexit story, it was widely retweeted. The correspondents' personal branding took several different forms: some used their posts to build up a picture of their lives outside politics (Mason), others uploaded numerous photographs of themselves (Peston), while others restricted their activity almost entirely to their coverage of the political story.

Kuenssberg has 831,000 Twitter followers and is one of the best known BBC reporters. But earlier in the year, she was quoted as saying that she was close to leaving social media because of the vitriol levelled at her (Thorpe, 2018). In a panel discussion about online abuse, she said:
The way that some online sites have given a megaphone to people who want to cause trouble, given the oxygen for that kind of thing, has actually in a way shut it down, and that is a shame.

But as the conference season progressed, Kuenssberg stepped up activity and promoted her own interviews with senior politicians such as Theresa May and her main challenger for the Conservative leadership Boris Johnson (5.9\% of her total tweets promoted directly her own interviews or online stories) At times her rapid-fire tweeting of live events was like that of a news agency. This was accompanied by frequent retweets of BBC news stories by colleagues, particularly those working in Europe on Brexit. In this fashion, Kuenssberg was using her Twitter feed as an additional online distribution channel for the $B B C$. Rarely did she tweet on matters outside the realm of politics.

Her BBC colleague Chris Mason was equally prolific but showed a more diverse and humorous range of interests beyond the political scene, giving his 66,000 Twitter followers a glimpse of his personal life. These ranged from complaining about workmen outside his home at 8 a.m. on a Sunday morning to Yorkshire pudding and crack-of-dawn starts. Mason used Twitter to promote heavily the BBC's 'Brexitcast' podcast, which he hosts with two colleagues, plus his appearances on BBC Breakfast television. He frequently cited his BBC colleagues, sometimes retweeting their work and sometimes commenting on personal issues. A large number of tweets were dedicated to a BBC colleague who had just died of cancer, while other tweets were humorous, featuring goldfish named after correspondents and the difficulties of moving house. In contrast, the BBC's John Pienaar was far less diverse in his posts. He used his Twitter feed predominantly to promote his own programme Pienaar's Politics. His tweets featured video live from outside locations or party conference venues and gave a run-down of his guest line-up.

Table 2. Twitter activity.

\begin{tabular}{|c|c|c|c|c|c|c|c|c|c|c|c|}
\hline \multirow{3}{*}{$\frac{\text { Journalist }}{\text { C Mason }}$} & \multirow{3}{*}{$\begin{array}{r}\text { Followers } \\
66,000\end{array}$} & \multirow{3}{*}{$\begin{array}{c}\text { Tweet } \\
264\end{array}$} & \multirow{3}{*}{$\begin{array}{c}\text { Retweet } \\
178\end{array}$} & \multirow{3}{*}{$\begin{array}{c}\text { Total } \\
442\end{array}$} & \multirow{3}{*}{$\begin{array}{c}\begin{array}{c}\text { Non-political } \\
\text { tweets }\end{array} \\
31\end{array}$} & \multicolumn{6}{|c|}{$\begin{array}{c}\text { Branding } \\
\text { (\% of total tweets/retweets) }\end{array}$} \\
\hline & & & & & & \multicolumn{2}{|c|}{ Self } & \multicolumn{2}{|c|}{ Colleague } & \multicolumn{2}{|c|}{$\begin{array}{l}\text { Other news } \\
\text { outlets }\end{array}$} \\
\hline & & & & & & 52 & $11.8 \%$ & 83 & $18.8 \%$ & 10 & $2.3 \%$ \\
\hline L Kuenssberg & 831,000 & 300 & 141 & 441 & 2 & 26 & $5.9 \%$ & 102 & $23.1 \%$ & 20 & $4.5 \%$ \\
\hline H Stewart & 22,500 & 126 & 266 & 392 & 0 & 4 & $1.0 \%$ & 120 & $30.6 \%$ & 44 & $11.2 \%$ \\
\hline F Islam & 261,000 & 239 & 80 & 319 & 0 & 19 & $6.0 \%$ & 82 & $25.7 \%$ & 18 & $5.6 \%$ \\
\hline R Peston & 909,000 & 199 & 23 & 222 & 8 & 62 & $27.9 \%$ & 0 & - & 17 & $7.7 \%$ \\
\hline F Elliott & 11,400 & 40 & 94 & 134 & 4 & 8 & $6.0 \%$ & 24 & $17.9 \%$ & 16 & $11.9 \%$ \\
\hline J Groves & 8,300 & 59 & 6 & 65 & 1 & 0 & - & 2 & $3.1 \%$ & 27 & $41.5 \%$ \\
\hline G Rayner & 9,100 & 36 & 3 & 39 & 3 & 0 & - & 10 & $25.6 \%$ & 4 & $10.3 \%$ \\
\hline J Pienaar & 66,000 & 32 & 4 & 36 & 0 & 31 & $86.1 \%$ & 1 & $2.8 \%$ & 0 & - \\
\hline G Gibbon & 40,000 & 22 & 0 & 22 & 0 & 22 & $100 \%$ & 0 & - & 0 & - \\
\hline
\end{tabular}


Kuenssberg's chief broadcast rival is ITV's Robert Peston, a former colleague who shot to fame with a series of scoops for the BBC during the 2008 financial crisis. Peston has 909,000 followers on Twitter and even a separate account called 'Robert Peston's Hair' (only 1,311 followers), emphasising the cult of personality around him. He routinely commented on the news, injecting his own opinion. In one tweet, he said: "Our economy has failed in its fundamental purpose of giving hope of a better life for most of us." He used his feed to hit back at critics who accused him of attacking the Labour Party leader Jeremy Corbyn after a summer in which the politician became embroiled in a bitter anti-Semitism row. When it came to analysing politics, Peston skirted the character limit on Twitter by posing a political question and then linking to a longer comment piece hosted on Facebook. He leveraged the potential of linked social media accounts more than some other correspondents and routinely tweeted to promote his television show 'Peston' or his recently published book. The shifting of his television slot to a Wednesday evening from Sundays was accompanied by the launch of his own Twitter emoji which appears automatically when '\#Peston' is typed by users. He often made fun of himself, uploading a video of himself presenting outside No. 10 Downing Street where he repeatedly dropped his earpiece. Almost $28 \%$ of his tweets promoted either his television programme, his appearances in news bulletins or linked to his commentaries. In the period he posted 22 pictures of himself to Twitter.

When it came to the other broadcasters, Sky's Political Editor Faisal Islam engaged mainly in tweeting breaking news from politicians and sometimes used multiple, numbered tweets (up to 10 in a stream)-a thread-to explore detail on a story. One of the Telegraph correspondents with a reputation for detailed knowledge of Brexit, Europe Editor Peter Foster ${ }^{3}$, has developed this further, posting a 20-tweet thread on talks in a way that allowed complex analysis. The tone of Islam's tweets was analytical and often attempted to contextualise the shifting political stances around the Brexit debate. He promoted his own scoop on BMW's decision to close down its Mini factory near Oxford for a month after Brexit plus an interview with Theresa May. He retweeted content and a promotional video for Sophy Ridge on Sunday, his Sky colleague's political talk show. He also leveraged Sky's name by tweeting programmes or news reports from his colleagues. In addition, he retweeted a campaign by Sky News to make TV debates a permanent feature of UK general elections. Channel 4's political editor Gary Gibbon took the most conservative approach to Twitter, linking to his blog and footage from the broadcaster's flagship 7 p.m. news programme. The tweets came with a full-size picture, often of Theresa May, and once of himself as a correspondent standing outside parliament.
The data showed that newspaper journalists tended to focus on recycling and promoting stories by their own colleagues or others working in Westminster, supporting the assertion by Behr that the Twitter culture can lead to a collaborative view of events $(2018$, p. 22). The Guardian's joint political editor Heather Stewart was by far the most active. She tweeted live breaking news from the weekly parliamentary questions session and from some of the party conferences. A large proportion of her activity (31.6\%) was made up of tweets or retweets which either cited her own stories or, in the majority of cases, featured the work of her colleagues or those on the sister newspaper The Observer. In one tweet, Stewart, who attended the Labour Party conference in Liverpool, wrote:

I am bloody proud to work for the paper that exposed the Windrush ${ }^{4}$ scandal, which Jeremy Corbyn spoke about so movingly in his conference speech yesterday. Just saying.

Unlike others, she frequently retweeted job adverts, both within journalism and also at political think tanks and other similar organisations. The Daily Mail's political editor Jason Groves tended to tweet breaking news from politicians, often drawing on interviews on Britain's Sunday television chat shows, either hosted by the BBC journalist Andrew Marr or Sky's Sophy Ridge. Gordon Rayner, The Telegraph's political editor, also used Twitter sparingly, sometimes posting breaking news (five tweets as Theresa May made her conference speech) but more often tweeting links to Telegraph stories by his colleagues. In one tweet, he congratulated a colleague at the newspaper on her front page 'splash' on Brexit, saying "Great work." Francis Elliott, The Times' political editor, was also on the lower end of the activity scale. Some $23.9 \%$ of his activity was in the form of tweets, retweets or links to articles by himself or his colleagues on the newspaper; he sometimes linked to the day's front page, at one stage praising its layout. He also promoted his own scoop on Brexit (and retweeted coverage of it by rivals). Through links and retweets, he paid tribute to journalists working in Kabul, showing solidarity with them by linking to a CNN story that detailed how they are being targeted by the Taliban. When Behr wrote his scathing article about how Twitter is poisoning politics, Elliott tweeted: "fwiw trying to build Twitter free hours into my day."

\subsection{What Lobby Correspondents Felt about Branding on Twitter}

The lobby correspondents interviewed all felt that Twitter had become an integral part of their daily practice, particularly as a news gathering and 'tip-off' mecha-

\footnotetext{
${ }^{3}$ Peter Foster is not one of the 10 political correspondents tracked for this research but also works on the mainstream Brexit story.

${ }^{4}$ The Guardian broke the story of the UK government's mistreatment of the so-called 'Windrush' immigrants to Britain who had arrived from the Caribbean in the years after World War Two. Windrush referred to the name of one of the ships that arrived in London from Jamaica in 1948.

${ }^{5}$ Fwiw-for what it's worth.
} 
nism. They used Tweetdeck ${ }^{6}$, alongside wire services as standard. Twitter, said one, is a very good 'radar screen' in the competitive environment of the political lobby. This clearly echoed research which has focused on Twitter's use as a reporting tool and how it has become a valuable 'beat' (Broersma \& Graham, 2013, p. 447). At the same time, they were acutely aware of potential pitfalls, not least the possibility for Twitter in the closed lobby environment to exacerbate the tendency to form what Behr calls "cartels of information" (2018, p. 22). One experienced lobby correspondent said:

It can bring with it a slavery of confirmation bias and group think and you have to be careful to separate out the reputable from the disreputable, the polemic from the fact-based-they all get mixed together into a sort of sludge.

The correspondents were accepting of the guidelines drawn up by their editorial managers and felt the relationship with social media had become more relaxed than when Twitter was new. The "corporate panic" of the early days had faded, said one. One broadcaster said the clear rule was nothing should be tweeted that you wouldn't say live on air and it made sense to be held to the same standard. They identified the biggest potential problem around retweeting third party content, one noting that journalists are being called out all the time for bias. This trend, he said, had become exacerbated in the past few years, with some people just wanting to shout at journalists. Several of the interviewees remarked that the political parties they report on are closely watching retweets for any sign of bias.

Several of the journalists interviewed said they felt under pressure to tweet from their employer. None had quotas but one suggested this pressure might explain the rush of retweets seen each morning, adding there were increasing expectations that he and his colleagues should promote themselves and encourage followers to click through to underlying stories. When questioned about how they tweeted, there was a wide spectrum of practices, from the very cautious to those who enthusiastically embraced the opportunity to brand themselves. One broadcast journalist said it clearly came more naturally to those who worked in television and radio since they tended in any case "to show more of themselves on air." He added:

I suppose I saw it as a chance to build your brand and that is a key part of its role...using Twitter is a way of gaining a visibility...a way of getting known by the people you want to talk to.

Their techniques varied widely. One said he used a "scattergun" approach, dropping material into his Twitter feed that he was interested in and he felt his followers might not otherwise see. All of them linked to longer news sto- ries and valued the ability to cross promote programmes, podcasts or panel discussions they or their colleagues were involved in. Some were happy to tweet information about their private lives, arguing it helped build their identity online and made them human. Others felt it was better to keep strictly to the political agenda and as such had a far more conservative approach to brand building. The practice of live tweeting breaking news also divided opinion. Some saw it as part of their job and a way of building their presence; others felt it was not their role to replicate a news agency. Despite the inherent dangers of Twitter, all those interviewed saw advantages beyond newsgathering. They believed a strong online profile would make them more marketable for any future career move and, for those working on newspapers, Twitter gave some the freedom to distance themselves from highly partisan and extreme editorial stances over Brexit.

While some of the lobby correspondents were more comfortable with the idea of branding themselves than others, all were accepting of it despite having started their careers in a traditional style of journalism. None felt they were crossing a line into commercial territory. One said he saw no ethical dilemma; another said it was natural given the importance of gaining online traction. One newspaper journalist thought it was only sensible given the competitive pressures faced in the news market:

We are all in a war for ears, a war for eyeballs, we are all trying to make our pieces more attractive and persuasive and it is therefore my job. I am not measured by how many clicks I get but the company is trying to build subscriptions.... feel it is my job to get people to look at my stuff and to promote the work of the paper-that's what pays my bills.

\section{Conclusion}

In this age of populism, polarised opinion and fake news, it comes as no surprise that Twitter should have become so deeply embedded in Britain's lobby reporting at Westminster. It may have started out as another reporting aid, but it is now an integrated part of the culture and identity of those who operate in it, accepted as a means of audience engagement and as a promotional tool.

The first research question (RQ1) asked how political correspondents brand themselves, their news organisation and the profession of journalism through Twitter. The activity of the 10 lobby correspondents followed showed that they all engage in building their own identity and brand but to very different degrees and by adopting different approaches. The broadcasters clearly felt more comfortable given the fact that they already receive considerable public exposure on air and routinely posted tweets to promote their own programmes or those of colleagues. Reflecting that on-air presence, their tweets often featured pictures of themselves, either preparing in studios or conducting interviews with politicians.

\footnotetext{
${ }^{6}$ Tweetdeck is a dashboard allowing multiple 'timelines' to be monitored at once.
} 
They were quite willing to make fun of their own on-air mishaps by using a form of self-deprecating humour, underscoring Molyneux's findings on the use of humour as a means of fostering journalists' relationship with their audience (2015, p. 932). By contrast, the newspaper journalists were generally less active and tended to promote the work of their colleagues. As such, the broadcasters blurred the lines between the professional and personal far more than the newspaper journalists. All of the correspondents gave credit to those working in other organisations if they had a scoop but those journalists were usually covering the same political story, reinforcing the impression that the lobby is an echo chamber. exuding a 'clubby' atmosphere in which journalists cooperate closely with each other despite competitive rivalries. Twitter allows them to monitor each other's stories and at the same time reinforces a conformity in their output.

All those interviewed were aware of their news organisation's code of conduct for social media and were cautious when retweeting (RQ2). The broadcasters were also acutely aware of oversight by the regulator Ofcom. While outside the scope of this article, the analysis of the 10 Twitter feeds shows that few of the lobby correspondents routinely expressed overt opinions although some sailed close to the wind and were able to do so mainly through their retweets. Those who were interviewed recognised the normative professional ideology of the separation between news and the business of news but none felt their activity on Twitter undermined this, illustrating a dissonance between stated values and actual practice. In effect, their branding activity had become quietly but clearly absorbed within the boundaries of what is considered to be acceptable journalism and normalised (RQ3). Despite a stated adherence to normative ideology, their actual practice bore the hallmarks of what, in a previous era, might have been called marketing. Their links to news stories increased their organisation's distribution channels, while their links to programming at times represented a classic promotional activity that might previously have been carried out by the business side of the operation. There was a strong suggestion from those interviewed that it made pragmatic sense to promote one's employer given the difficult financial state of the industry. This would suggest that news organisations are succeeding in drawing on Twitter as a tool to engage audiences and bolster their business without overt opposition even from senior journalists. While the discourse of normative values of separation remained intact, in practice the lobby correspondents were engaging in creating, developing and maintaining their brand while cross promoting that of their colleagues, their news organisations and, at times, their campaigns. In this environment of UK political reporting such branding has become normalised as part of daily journalistic practice and in this respect the boundary has been quietly breached. As one broadcast journalist said: "If there is a line I have crossed, I have not noticed crossing it."

\section{Acknowledgments}

I would like to thank those journalists who took time out of their hectic reporting schedule to talk to me about their use of Twitter. I would also like to thank the anonymous reviewers of this article for their valuable input.

\section{Conflict of Interests}

The author declares no conflict of interests.

\section{References}

Artemas, K., Vos, T. P., \& Duffy, M. (2018). Journalism hits a wall: Rhetorical construction of newspapers' editorial and advertising relationship. Journalism Studies, 19(7), 1004-1020.

Barnard, S. R. (2016). 'Tweet or be sacked': Twitter and the new elements of journalistic practice. Journalism, 17(2), 190-207.

Barthel, M. L., Moon, R., \& Mari, W. (2015). Who retweets whom: How digital and legacy journalists interact on Twitter. Tow Center for Digital Journalism. Retrieved from http://towcenter.org/research/who retweets-whom-how-digital-and-legacy-journalistsinteract-on-twitter

BBC. (2015). Social media guidelines for staff. Retrieved from http://news.bbc.co.uk/1/shared/bsp/ hi/pdfs/26_03_15_bbc_news_group_social_media_ guidance.pdf

BBC. (2018). Editorial guidelines. Social networking, microblogs and other third party websites. BBC. Retrieved from https://www.bbc.co.uk/editorialguide lines/guidance/social-networking-microblogs

Behr, R. (2018). How Twitter poisoned politics. Prospect. Retrieved from https://www.prospectmagazine.co. uk/magazine/how-twitter-poisoned-politics

Bloom, T., Cleary, J., \& North, M. (2016). Traversing the "Twittersphere". Journalism Practice, 10(3), 343-357.

Bossio, D., \& Sacco, V. (2017). From "selfies" to breaking Tweets: How journalists negotiate personal and professional identity on social media. Journalism Practice, 11(5), 527-543.

Brems, C., Temmerman, M., Graham, T., \& Broersma, M. (2017). Personal branding on Twitter: How employed and freelance journalists stage themselves on social media. Digital Journalism, 5(4), 443-459.

Broersma, M., \& Graham, T. (2013). Twitter as a news source. How Dutch and British newspapers used tweets in their news coverage, 2007-2011. Journalism Practice, 7(4), 446-464.

Carlson, M., \& Lewis, S. C. (2015). Boundaries of journalism: Professionalism, practices and participation. London: Routledge.

Chadha, K., \& Wells, R. (2016). Journalistic responses to technological innovation in newsrooms: An exploratory study of Twitter use. Digital Journalism, 4(8), 1020-1035. 
Channel 4. (2018). Social media guidelines. Channel 4. Retrieved from https://www.channel4.com/producershandbook/c4-guidelines/social-media-guidelines

Coddington, M. (2015). The wall becomes a curtain: Revisiting journalism's news-business boundary. In M. Carlson \& S. C. Lewis (Eds.), Boundaries of journalism: Professionalism, practices and participation (pp. 79-94). London: Routledge.

Cornia, A., Sehl, A., \& Nielsen, R. K. (2018). 'We no longer live in a time of separation': A comparative analysis of how editorial and commercial integration became a norm. Journalism. https://doi.org/10.1177/ 1464884918779919

Couldry, N. (2012). Media, society, world: Social theory and digital media practice. Cambridge: Polity.

Duffy, A., \& Knight, M. (2018). Don't be stupid: The role of social media policies in journalistic boundarysetting. Journalism Studies. https://doi.org/10.1080/ 1461670X.2018.1467782

Gieryn, T. F. (1983). Boundary-work and the demarcation of science from non-science: Strains and interests in professional ideologies of scientists. American Sociological Review, 48(6), 781-795.

Hanusch, F., \& Tandoc, E. C., Jr. (2017). Comments, analytics, and social media: The impact of audience feedback on journalists' market orientation. Journalism. https://doi.org/10.1177/1464884917720305

Hermida, A. (2010). Twittering the news. Journalism Practice, 4(3), 297-308.

ITV. (2018). ITV social media legal \& compliance guidelines. Retrieved from https://www.itv.com/_data /documents/pdf/producers_handbook_oct2018.pdf

Lough, K., Molyneux, L., \& Holton, A. E. (2017). A clearer picture: Journalistic identity practices in words and images on Twitter. Journalism Practice, 12(10), 1277-1291.

Lysak, S., Cremedas, M., \& Wolf, J. (2012). Facebook and Twitter in the newsroom: How and why local television news is getting social with viewers? Electronic News, 6(4), 187-207.

Mayer, J. (2011). A resource for newsrooms: measuring the success of audience engagement efforts. Journalism accelerator. Retrieved from http://journalism accelerator.com/resources/a-resource-for-newsrooms -measuring-the-success-of-audience-engagementefforts

Molyneux, L. (2015). What journalists retweet: Opinion, humor, and brand development on Twitter. Journalism, 16(7), 920-935.

Molyneux, L., \& Holton, A. E. (2015). Branding (health) journalism: Perceptions, practices, and emerging norms. Digital Journalism, 3(2), 225-242.

Molyneux, L., Holton, A. E., \& Lewis, S. C. (2018). How journalists engage in branding on Twitter: Individual, organizational, and institutional levels. Information, Communication \& Society, 21(10), 1386-1401.

Molyneux, L., \& Mourão, R. R. (2017). Political journalists' normalization of Twitter: Interaction and new affor- dances. Journalism Studies, 20(2), 1-19.

Murphy, J. M. (Ed.). (1987). Branding: A key marketing tool. London: Macmillan.

Olausson, U. (2017). The reinvented journalist: The discursive construction of professional identity on Twitter. Digital Journalism, 5(1), 61-81.

Opgenhaffen, M., \& Scheerlinck, H. (2014). Social media guidelines for journalists. Journalism Practice, 8(6), 726-741.

Ottovordemgentschenfelde, S. (2017). 'Organizational, professional, personal': An exploratory study of political journalists and their hybrid brand on Twitter. Journalism, 18(1), 64-80.

Parmelee, J. (2013). Political journalists and twitter: Influences on norms and practices. Journal of Media Practice, 14(4), 291-305.

Revers, M. (2015). The augmented newsbeat: Spatial structuring in a twitterized news ecosystem. Media, Culture \& Society, 37(1), 3-18.

Richards, I. (2004). Stakeholders versus shareholders: Journalism, business, and ethics. Journal of Mass Media Ethics, 19(2), 119-129.

Rusbridger, A. (2018). Breaking news. The remaking of journalism and why it matters now. Edinburgh: Canongate Books Ltd.

Sacco, V., \& Bossio, D. (2017). Don't tweet this! How journalists and media organizations negotiate tensions emerging from the implementation of social media policy in newsrooms. Digital Journalism, 5(2), 177-193.

Siapera, E. (2018). Understanding new media. London: Sage.

Singer, J. (2015). Out of Bounds-Professional norms as boundary markers. In M. Carlson \& S. C. Lewis (Eds.), Boundaries of journalism: Professionalism, practices and participation (pp. 33-48). London: Routledge.

Sky. (2017). Sky News editorial guidelines. Sky. Retrieved from https://assets.publishing.service.gov.uk/gov ernment/uploads/system/uploads/attachment_data /file/654196/16E3_-_A_O_to_DCMS_21.06.2017_ UILS_enclosure_3.pdf

Tandoc, E. C., Jr., \& Vos, T. P. (2016). The journalist is marketing the news: Social media in the gatekeeping process. Journalism Practice, 10(8), 950-966.

The Telegraph. (2018). Editorial and commercial guidelines. The Telegraph. Retrieved from https://www. telegraph.co.uk/about-us/editorial-and-commercialguidelines

Thorpe, V. (2018, July 22). I nearly quit 'ugly' social media, says Laura Kuenssberg. The Guardian. Retrieved from https://www.theguardian.com/media/2018/jul/22/ kuenssberg-politics-social-media-bullying-threats-bbc -canary-corbyn

Vis, F. (2013). Twitter as a reporting tool for breaking news. Digital Journalism, 1(1), 27-47.

Waisbord, S. (2013). Reinventing professionalism: Journalism and news in global perspective. Cambridge: Polity Press. 


\section{About the Author}

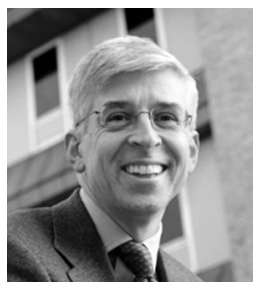

Stephen Jukes is Professor of Journalism at Bournemouth University. His research focuses on areas of objectivity and emotion in news with an emphasis on affect, trauma and conflict journalism. Before becoming an academic, he had been a foreign correspondent and editor for Reuters across the world. He worked on a wide array of stories ranging from the ousting of Margaret Thatcher and fall of the Berlin Wall to the September 11 attacks in 2001 when he was Reuters Global Head of News. 